DOI: $10.1515 / \mathrm{rpp}-2016-0024$

Lecturer, ALLA ZASLUZHENA

National Aviation University, Ukraine

Address: 1 Kosmonavta Komarova Ave, Kyiv, 03680, Ukraine

E-mail: alla130373@mail.ru

\title{
THE CONCEPT OF ENGLISH PHILOLOGISTS' TRAINING AT SWISS UNIVERSITIES
}

\begin{abstract}
The issue of plurilingual approach usage to the study of foreign languages has been made actual on case study of Swiss universities. Basic concepts of English philologists' formation at Swiss universities have been determined. These components have been analyzed with relation to their relevance to the prospective philologist in English Linguistics and Literature. The attention has been focused on the effectiveness of Swisss higher education up to the indicator "skills" (Global Information Technological Report 2014, Networked Readinnes Index, NRI) according to the World Economic Forum on the development of information technologies in different countries. The emphasis has been made on mutual interaction between sectors of secondary and higher education, that contributes to the quality improvement of education in the country. Some steps in the process of modernization in primary and secondary education have been indicated, such as the usage of the Swiss version of the European Language Portfolio; development of "Profession-related Language Competence Profile for Foreign Language Teachers at Lower Secondary Schools", "The Passepartout Language Teacher Profile". Attention is paid to the following changes of teachers' training: its belonging to tertiary study; mandatory practice-teach for English teachers in English-speaking countries, the required level of command of English language as admission to study in Bachelor and Master programs; capability to work in other linguistic regions, which in turn causes the requirements on quality assurance of particular region language proficiency according to the CEFR (Common European Framework of Reference for Languages).
\end{abstract}

Key words: concept, philologist, English language and literature, higher education, standards of higher education, plurilingual approach, Master.

\section{INTRODUCTION}

More and more scientists (D. Elsner, S. Filice, B. Grossenbacher, B. Hufeisen, U. Jessner, G. Neuner, R. Pugliese) support multilingual approach or plurilingual didactics in formation of prospective philologists (Schwab-Berger, 2015).

Switzerland is the country that widely uses multilingual paradigm and plurilingual approach to foreign languages learning, which was defined as the leading one by the Council of Europe. The core of this approach is that "in the process of expanding individual linguistic experience of an individual in its cultural aspects from the level of everyday conversation to language community in broad sense and then to the languages of other nations, the individual does not sense these languages as clearly defined mental blocks, but communicative competence is formed, within all linguistic knowledge and experience are components and in which languages intertwine and interact" (Ніколаєва, 2003; Заслужена, 2015). 
Experience of Swiss universities to form professionals in English Philology is important to improve philological training at Ukrainian universities as it will help the successful harmonization of national higher humanitarian education expanse with European higher verbal training. Understanding of conceptual foundations training at Swiss universities will contribute to rational selection of the most appropriate components of this experience and its implementation in the educational system of training and education of Foreign Philology specialists' personality at Ukrainian universities.

\section{THE AIM OF THE STUDY}

The analysis of theoretical sources indicates on the lack of fundamental results of special researches that would reflect the concept of Master training at Swiss universities, which, in turn, determined the purpose of this article to reveal the basic concepts of teachers training in English language and literature at the universities of Switzerland.

\section{THEORETICAL FRAMEWORK AND RESEARCH METHODS}

The problem of realization of public education that caused by computerization of society brings scientifically practical interest, as indicated by the large number of studies on the subject, including scientists like M. Leschenko (М. Лещенко, 2014), A. Yatsyshyna (Яцишина, 2014). The authors note that "open (public) education is an integral part of the information society, reflects the general trend of consistent educational processes transition from one condition to another, forming designating informative and communicative basis of education". This issue is actualized in scientific works of V. Bykov, Zh. Chupahina, M. Chvanova, A. Ishchenko, O. Korolova, V. Lupanov, V. Mojsyeyev, V. Sokolov, V. Soldatkin, O. Vysotska, O. Zaharova and others (Лещенко, Яцишина, 2014).

The Swiss education system is a public social system (Заслуженная, 2013). Switzerland ranks the sixth in the network readiness index and the first in the quality of its education system up to the indicator "skills" (Global Information Technological Report 2014, Networked Readinnes Index, NRI), according to the World Economic Forum on the development of information technologies in different countries.

Switzerland is one of the few countries that impose serious requirements to foreign language teachers, as it is evident from the description of situations in various European countries, from the report "Key Data on Teaching Languages at School (Education, Audiovisual and Culture Executive Agency, 2012)" (Buechel, 2014). This issue is investigated by native scientists, too. So, in particular, it has been studied in works of researchers such as N. Bidyuk, L. Pukhovska, O. Semenog in terms of Philology Masters' formation in Ukraine and abroad.

Such foreign scientists as P. Gonon, T. Bieber, S. Hof, S. C. Wolter, L. Loder Buechel, S. Rosmarie Schwab-Berger handled the problem of Swiss higher education in various aspects. However, the experience of Switzerland in training Masters in Philology has not been considered by scientists and practitioners.

On this basis we consider it appropriate to prove the concept of English Philology specialists' training at Swiss universities using these research methods: interpretive and analytical methods - to study Ukrainian and foreign sources using synthesis, analysis, classification and generalization, comparative historical analysis, which made it possible to find out the peculiarities of foreign language teachers at universities in Switzerland.

\section{RESULTS}

Concept from Latin conceptio is understanding, a system. It is a way of understanding and interpretation of any events; the main view, fundamental idea of their showing. We hold authors' standpoint of the new dictionary of the Ukrainian language on 
the definition of the term "concept": this is a system of certain statement evidences, a world view on this or that phenomenon; world conception, views, beliefs (Яременко, Сліпушко, 1998).

The concept of Masters' in English language and literature training at universities in Switzerland has been founded and proved on structural, organizational and content levels. It was formed in consideration of following concepts: international and intranational document base of higher education organisation in the country; cooperation between higher education institutions; admission peculiarities to higher education institutions and Master training programs on the base of Bachelor's degree; trends of Masters' in English Language and Literature training and features of the organization of the training process; specificity of content as an indicator of the direction of specialists' professional training in English language and literature; the role of teaching practice in the English language and literature teachers' training; methodological approaches to foreign languages teaching at universities; continuing education.

With regard to the concept of "international and intranational document base of higher education organisation in the country", we note that national documentary base of Swiss higher education has been harmonized with fundamental principles of the Common European Higher Education Area Establishment (Заслужена, 2013).

In Switzerland Universities of Basel, Fribourg, Geneva, Berne, Zurich (Заслужена, 2015) and pedagogical universities (Pedagogical University of Bern, Zurich University of Teacher Education Lucerne) train Masters in English language and literature.

As for the concept of Master in English language and Literature training trends, we note that qualification, which is awarded to Master qualified as "English Language and Literature" providing his/her successful completion of training allows him/ her to work as a teacher, not only in English at the lower secondary school level, but also a teacher of others subjects (which he/she chose to train at the university); in upper secondary school he/ she can be a bilingual teacher, a teacher of the subject and language; a teacher with the subject qualifications and language skill set in the subject; Matura school teacher (suitable for teaching English and other 2-3 subjects or only English). To work as a teacher at pedagogical universities with specialization in one of the languages, including English, it is needed to get a Master's degree in foreign (English) didactics (120 credits), which also provides other career opportunities, but does not give the right to work as a teacher at school.

With regard to the training by pedagogical universities it has been found out that a Master must complete the appropriate certification for the acquisition opportunity to work by occupation. In particular for the English (or French) language teaching at elementary school, he/ she must meet the following requirements: accumulate 4-6 ECTS credits in English / French language teaching at primary school level; undergo a three-week practice "Teacher-Assistant" in a country where English / French is the language of instruction; present evidence of English / French language proficiency at level C1 (what for it is necessary to pass the relevant exam) (Buechel, 2015).

Preparation course for teachers of gymnasium school at pedagogical university of Fribourg covers the scientific section - two educational subjects I and II, taught at the respective faculties of the university and the section on education and didactics that includes courseworks and practical training in education, teaching psychology, didactics (general and specialized) and teaching practicum (Universite de Fribourg, 2016).

A brief analysis of the content of Bachelors' in English language and literature training at universities in Switzerland reveals that the students of this educational level are qualified as philologists by mastering linguistic content of subjects, the disciplines of literary studies and the content from literature belonging to a certain period (Барановська, 2015). 
As for the concept of cooperation between higher education institutions in Switzerland, it should be noted that this practice is encouraged and widespread. For example, joint Master program in English, actualized between the Swiss University of St. Gallen, Zurich, Graubünden, Schaffhausen, Thurgau and teaching universities in other countries: Weingarten (Germany), Vorarlberg (Austria); "Master's in School Development" or e-project "SWISSLING" in developing of its courses content the department of the Institute of linguistics and semiotics of the Faculty of Communication Sciences in Lugano, Department of Linguistics, University of Geneva and Lausanne, Department of Romance Languages, Universities of Basel and Zurich involved.

As for the concept of admission peculiarities to higher education institutions and Master training programs on the base of Bachelor's degree, it should be considered that universities require from applicants thorough command of a language of instruction in the chosen institution of higher education. For admission to Swiss universities Swiss maturity certificate or foreign school certificate of upper secondary school completion of equal value are valid, which gives the right admission to the university; different types of certificate of Bachelor from schools with Bachelor's degree (except international Bachelor Certificate for which there are restrictions) (Perellon, 2001).

Those holders of Bachelor's degree, who have English language proficiency at level C1 and C2 of the CEFR (Common European Framework of Reference for languages), are enrolled to Swiss universities (Заслужена, 2015), indicating the orientation of the language policy of the country to European standards and the usage of competency-based approach. These individuals successfully mastered all courses of Bachelor program and defended their theses or fulfilled other prescribed requirements for certification (Bachelor program can be designed for 60,90, 120 credits relatively the English language and literature study) (Барановська, 2016). The university in Fribourg for English teachers offers a program that is designed for 50 credits and includes the study of English language and literature, language course, a report on a sojourn in English-speaking country for a specified term, the course of translation; lectures (with second language acquisition, language teaching methods, assessment and evaluation); course in didactics.

As for the concept of organization of Master in English language and literature training it should be noted that Master's program for English language and literature philologists at Swiss universities differ in the number of credits $(120,60$ or 30 credits ESTS) and a choice of specialization in linguistics or literature. In addition to these programs, for example, pedagogical University of Fribourg offers various Master's programs consisting of 60, 180 credits: for Matura schools teachers (with the ability to teach English and other subjects, or only 2-3 English language); for teachers at pedagogical universities with specialization in one of the languages, including English. The general entry requirement for these programs is the level of English, equivalent to level C1 of the CEFR.

The concept of the specificity of content as an indicator of the direction of English language and literature philologists' professional training is revealed in that Bachelors who studied at Swiss universities, are able to engage in research activities in English on English linguistics and literature. Swiss Bachelors have well-formed communicative competence. In our opinion, this contributed by plurilingual approach, functional plurilinguizme that were methodological approaches to Bachelor of English Language and Literature study, which encouraged students to communicative interaction, i.e used language for understanding, without focusing on its mastery.

Regardless the type of university (either university or pedagogical university), Master of mentioned qualifications speaks English in a professional manner, is competent 
in other areas based on his/ her own interests, is able to conduct research in English Language and Literature (depending on his/her specialization). Proof of this assertion is the fact that students are allowed to participate in projects of three research institutes of the pedagogical university of Lucerne working for public and private institutions. Research work carried out by these institutions, is dedicated to issues of teachers training and their impact on the development of school culture, classroom management; cognitive issues (learning and strategies, knowledge transfer and measurement of effectiveness), issues related to the problems of multiculturalism in teaching (Заслужена, 2015).

As for the concept of the role of teaching practice for teachers' training in the English language and literature in the Swiss Confederation it should be indicated that Swiss pedagogical universities support the allocation of $20-30 \%$ of total teaching time in class to practice (Santiago, 2004). Swiss students are to practice in partner secondary schools but not at universities. Teachers of Swiss partner schools can influence the content of pedagogical universities' curriculum. We think this is due to close cooperation between secondary education sector and tertiary sector and the fact that reforms in education began with primary and secondary schools.

To modernize primary and secondary education were taken some steps, such as compulsory introduction of two languages, one of them - English (until 11 years), the usage of the Swiss version of the European Language Portfolio that integrates all languages, mother tongue/migration and take into consideration intercultural aspects, different experiences of language learning (such as strategies) and all learning contexts: out-of-class and academic (according to the curriculum) and linked to the CEFR, which enables to document (record) the quality of language acquisition and levels of intercultural competence in the transition to a higher level of training and language practical usage; developed "Profession-related language competence profile for foreign language teachers at lower secondery schools", "The Passepartout Language Teacher Profile".

Teacher training has also undergone reforming: position of teacher training has been changed. It belongs to tertiary education now. Among other changes are: mandatory practice-teach for English teachers in English-speaking countries, the required level of command of English language as admission to study in Bachelor and Master program; capability to work in other linguistic regions, which in turn causes the requirements on quality assurance of particular region language proficiency according to the CEFR.

Thus, in general mutual interaction sectors of secondary and higher education contributes to the quality improvement of education in the country.

As for the concept, concerning methodological approaches to the teaching of foreign languages at Swiss universities note: Master training of English philologists at these universities is characterized by the formation of students plurilingual competence, its elements are: knowledge acquirement in the field of linguistics, acquirement of culture, experience acquirement in listening through comparative phonetic analysis of languages, mastering of interactivity means, constant dialogue with language speaker (Чубарова, 2016), creating awareness in second language acquisition. This is made possible by the intensification of training due to the support of the first foreign language and a significant amount of information to read in English.

Our research has determined that the University of Zurich uses lesson plans for teachers as didactic resource, which are based on CLIL approach (Content and Language Integrated Learning), called "Zurich approach" (Suter, 2016). These plans include designed tasks in comparison, generalization, systematization according to various topics. CLIL 
approach is an example of the usage of "an integrated approach to the didactics of different languages" to the multilingual and multicultural education.

Regarding Internet technology usage we note that in Switzerland virtual teaching and learning has not completely replaced the traditional, and it is used to strengthen traditional education and wide-scale distributed with different platforms using in the levels of compulsory and higher education. Platforms "Educanet I", "Educanet 2" are used at the level of compulsory education, "Moodle" and "ILIAS" - in upper secondary school and universities, Moodle, Dokeos, OLAT, ILIAS, UNIBE and others - in universities. This gives us a reason to say that "integrative concept: e-learning as a mandatory component of teaching and learning" is applied in Switzerland (Засанська, 2012).

As for the concept of continuing education, we note that in Switzerland the problem of continuous professional development of specialists in foreign languages is particular relevant. The Swiss system of teacher professional development is based on the idea of counseling in the workplace by more experienced colleagues and realized through the induction system (the inclusion system of teacher education graduates to the profession), based on certain principles. Among them are provision of necessary assistance to a new teacher without assessment of his or her activities; teachers consideration as adult learners; problem solving arising from the practice; consideration of induction process as a phase that focuses on personal development and teachers professionalism; implementation of special institutional and staff efforts.

\section{CONCLUSIONS}

Generalisation of the foregoing allows to determine the following main characteristics of Master training of English philologists at universities in Switzerland: harmonization of its intra-national documentary base of higher education with European higher education; ensuring of cooperation between higher education institutions; presence of admission features to higher education institutions and academic programmes at Master's degree programmes on the base of Bachelor's programmes, that give evidence of determination of the country language policy to European standards and the usage of competency-based approach; credit-orientation of Master' professional training in English language and literature; opportunities to choose specialization in linguistics or literature; peculiarities of the content determine the direction of professional training of professionals in English language and literature; significant role allotment to teaching practice of applied nature in teachers training of English language and literature; leading methodological approach to teaching foreign languages at universities is plurilingual; continuing education has acquired special topicality.

For the first time revealed features of the concept of Masters training in English language and Literature at the universities of Switzerland contribute to the improvement of the concept of Master training in English language and Literature at local universities, underpinning of perspective directions of Swiss experience in the practice of professional training in foreign languages in higher education in Ukraine.

\section{REFERENCES}

1. Buechel, L. L. (2014). Associations between Young Learners' English Language Performance and Teacher Proficiency and Experience with English PhD Thesis: Universite de Fribourg. Retrived 15.04.2016 from : http://doc.rero.ch/record/234689/files/LoderBuech elL.pdf. 
2. Buechel, L. L. (2015). Young Learner Writing Performance in Swiss Elementary Schools - Which Teacher Variables Matter? Retrieved 15.04.2016 from : http://phzh.ch/ MAPortrait_Data/55324/19/RELC\%20Journal-2015-Loder\%20Buechel-0033688215598437.pdf

3. Perellon, J. F. (2001). The Governance of Higher Education in a Federal System: the Case of Switzerland. Tertiary Education and Management, Volume 7, Issue 2, pp. 211-224.

4. Santiago, P., Thieme, Ch., Zay, D., Wagner, A. (2004). Attracting, Developing and Retaining Effective Teachers Country Note: Switzerland. Retrieved 15.04.2016 from : https://www.oecd.org/switzerland/33684152.pdf.

5. Schwab-Berger, S. (2015). Teachers' Perceptions of the Implementation of a Multilingual Approach to Language Teaching. Retrieved 15.04.2016 from : http://scholarworks. waldenu.edu/cgi/viewcontent.cgi? article $=1762 \&$ context $=$ dissertations.

6. Suter, Ch. (2016). Training CLIL Teachers: The Zurich Approach. Retrieved 15.04.2016 from : http://www.onestopenglish.com/clil/clil-teacher-magazine/your-perspectives/ training-clil-teachers-the-zurich-approach/501206.article.

7. Universite de Fribourg. (2016). Teacher Education for Academic Upper Secondary Schools. Retrieved 15.04.2016 from : http://studies.unifr.ch/en/master/teach/teacheredu2.

8. Барановська, Л., Заслужена, А. (2015). Особливості змісту підготовки бакалавра 3 англійської мови та літератури в університетах Швейцарської Конфедерації [Content Peculiarities of Bachelor's in English language and Literature Training at Universities of Switzerland]. Порівняльна професійна педагогіка [Comparative Professional Pedagogy], Volume 5, Issue 1, pp. 148-153 (in Ukrainian).

9. Засанська, С. (2012). Сучасні тенденції впровадження й фінансування електронного навчання [Current Trends and the Introduction of E-Learning Funding]. Електронне наукове фахове видання «Ефективна економіка» [Electronic Scientific Specialized Edition "Effective Economy"], No 9. Retrieved 15.04.2016 from : http://www. economy.nayka.com.ua/?op=1\&z=1413.

10. Заслуженная, А. (2013). Гармонизация системы высшего образования Швейцарской Конфедерации с европейским пространством высшего образования [Harmonization of Swiss Higher Education System with the European Higher Education Area]. In: Proceedings of the International Scientific-Practical Conference on Actual Scientific Issues and Modern Educational Technologies (28.06.2013). Тамбов : Изд-во ТРОО «БизнесНаука-Общество», pp. 69-71 (in Russian).

11. Заслужена, А. (2015). Методичні рекомендації з удосконалення підготовки майбутніх філологів з англійської мови та літератури у ВНЗ України [Guidelines for Improving Training of Future Philologists in English Language and Literature at Ukrainian Universities]. Вісник Національного авіаційного університету. Серія: Педагогіка. Психологія [National Aviation University Journal. Series: Pedagogy. Psychology], No 2 (7), pp. 57-62 (in Ukrainian).

12. Заслужена, А. (2015). Особливості підготовки майбутніх вчителів в педагогічних університетах Швейцарської Конфедерації [Peculiarities of Prospective Teachers' Training at Pedagogical Universities of Switzerland]. In: the Proceedings of the $3^{\text {rd }}$ International Scientific Conference on Topical Problems of Higher Education in Ukraine (19.03.2015). K. : HAУ, p. 41 (in Ukrainian).

13. Заслужена, А. (2015). Підготовка філолога 3 англійської мови та літератури у ВНЗ Швейцарської Конфедерації (на прикладі університету Фрібура) [Training of Teachers in English language and Literature at Universities of Switzerland (based on the University of Fribourg)]. Наукові записки Рівненського державного 
гуманітарного університету [Scientific Notes of Rivne State Humanitarian University], No 12 (55), pp. 519-527 (in Ukrainian).

14. Лещенко, М., Яцишин, А. (2014). Відкрита освіта у категоріальному полі вітчизняних і зарубіжних учених [Open Education in Categorical Field of Native and Foreign Scientists]. Інформачійні технологї $і$ засоби навчання [Information Technologies and Learning Tools], Volume 39, Issue 1, pp. 1-16 (in Ukrainian).

15. Ніколаєва, С. (2016). Загальноєвропейські Рекомендації з мовної освіти: вивчення, викладання, оцінювання [Common European Framework of Reference for Languages: Learning, Teaching and Assessment]. Retrieved 15.04.2016 from : http://kievskiyruo.edu.kh.ua/Files/downloads/zagalnoyevrop_rekom.doc.

16. Чубарова, Л. (2016). Особенности формирования плюрилингвистической компетенции студентов в процессе иноязычного образования в вузе [Features of Students' Plurilingual Competence Formation in the Process of Foreign Language Education at University]. Retrieved 15.04.2016 from : http://www.de.utmn.ru/docs/351.pdf.

17. Яременко, В., Сліпушко, О. (1998). Новий тлумачний словник украйнськой мови у чотирьох томах [New Dictionary of the Ukrainian Language in Four Volumes], Volume 2, 911 p. (in Ukrainian). 